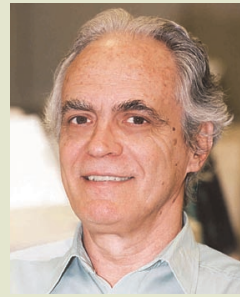

Paulo Sandroni FGV-EAESP paulo.sandroni@fgv.br

\title{
A crise americana
}

COM AS BAIONETAS SE PODE FAZER TUDO. MENOS SENTAR EM CIMA DELAS

A frase é atribuída a um famoso general francês que, dizem, morreu envenenado. O mesmo se aplica à taxa de juros: única arma rápida e eficiente contra a desaceleração da economia norteamericana, mas que tem seus limites.

Em janeiro de 2008, duas reduções somando $1,25 \%$ jogaram a Prime Rate para 3\%. O presidente Bush, para reforçar, acenou com cortes de impostos e com a introdução de subsídios pensando que dissiparia as incertezas, mas foi como anunciar que o gladiador era um anão. Na Europa uma "espiroqueta" do mercado financeiro foi descoberto provocando um descomunal rombo em um dos maiores bancos franceses. As bolsas despencaram, lembrando o refrão: quando sobem, sobem mais do que podem; quando caem, caem mais do que devem.

Até que ponto a Prime Rate deve encolher para estimular o consumo e o investimento produtivo, neutralizando a crise originada nas hipotecas subprime e evitar a recessão? Ou então: em uma sociedade viciada em consumo, a redução exagerada dos juros não provocaria um enfraquecimento do dólar, a expansão da demanda e pressões inflacionárias indesejadas em um ano eleitoral?

Creio que os americanos ainda deverão sofrer muitos traumas para passar da idolatria à aversão ao consumo. Em todo caso, o mais provável é que o consumo caia e os americanos tenham que conviver com a recessão combinada com consideráveis pressões inflacionárias - fenômeno típico dos anos 1970 e batizado como estagflação.
É preciso lembrar também que a taxa de juros básica norte-americana caiu abaixo da taxa de juros do Banco Central Europeu, enfraquecendo ainda mais o dólar frente ao euro. A rolagem do enorme endividamento americano não estaria em perigo? Ou haveria uma espécie de armadilha para aqueles que aplicaram suas reservas em títulos do Tesouro Americano? E nós?

Bem, hoje o Brasil parece estar melhor preparado para enfrentar a desaceleração da economia mundial. Um sintoma interessante é que, em janeiro de 2008, a fuga de capitais especulativos que provocou a queda na Bovespa foi em grande medida compensada pela entrada de investimentos produtivos que se movem por considerações de médio e longo prazo.

A blindagem das reservas parece razoavelmente sólida, garantindo a estabilidade do câmbio no curto prazo e, por extensão, segurando a inflação. A manutenção da taxa Selic no Brasil acima dos $11 \%$ é o único fator negativo que alimenta o crescimento da dívida interna e segura a onda expansiva dos investimentos e do consumo.

O fato é que não aproveitamos a boa conjuntura internacional dos últimos cinco anos. Nosso expressivo crescimento em 2007 parece ter chegado no fim da festa. O PIB de 2008 talvez acuse os golpes da retração nos Estados Unidos e o sólido impulso de 2007 poderá em parte desmanchar-se no ar. 